\title{
Contraction of Collagen Gels by Intestinal Epithelial Cells Depends on Microfilament Function
}

\author{
ALLAN DAVID OLSON, MD
}

\begin{abstract}
We have developed a model system to quantify the tractional forces generated by intestinal epithelial cells during organization into a confluent epithelial cell sheet. In this model system, IEC-6 cells, a rat intestinal crypt cell line, rapidly contracted collagen gels reducing the gel surface area by $97 \%$ at $24 \mathrm{hr}$. The tractional forces measured by gel contraction were directly related to the number of cells added and were inversely related to the collagen concentration of the gel. Actin microfilament function was required for gel contraction, but microtubular function was not. Fetal bovine serum and protein synthesis were required for maximal gel contraction. IEC-6 $\left(5 \times 10^{5}\right)$ cells per gel and fibroblasts $(5$ $\left.\times 10^{4}\right)$ cells added to collagen gels resulted in contraction of the gels by $50 \%$ at $24 \mathrm{hr}$. Therefore, intestinal epithelial cells and fibroblasts generate tractional forces of similar strength capable of organizing the surrounding extracellular matrix, which should be considered in models of intestinal morphogenesis and repair.
\end{abstract}

KEY WORDS: intestinal epithelial cells; collagen gels; contraction; tractional forces.

Cellular interactions with the extracellular matrix (ECM) are critical for the organization of individual epithelial cells into a cohesive, polarized tissue $(1$, 2). Specifically, IEC-6 cells, a rat intestinal crypt cell line (3), require binding to laminin for organization into multicellular epithelial sheets (4). Tractional forces generated by cells play critical roles in both embryogenesis $(5,6)$ and wound healing $(7,8)$. Fibroblasts grown on type I collagen gels extensively modify the collagen gels (7-15). This contraction of collagen gels composed of reconstituted collagen fibrils by fibroblasts in vitro is used by many

\footnotetext{
Manuscript received August 16, 1991; revised manuscript received August 5, 1992; accepted August 10, 1992.

From the Department of Pediatrics, Schneider Children's Hospital, Long Island Jewish Medical Center, State University of New York at Stony Brook, Stony Brook, New York.

Address for reprint requests: Dr. Allan D. Olson, Division of Pediatric Gastroenterology, University of Michigan Medical Center, C6105 MIB, Box 0800, Ann Arbor, Michigan 48109.
}

investigators as a model of wound healing in vivo $(7-9,14,15)$.

Although repair of defects in the epithelial lining of the intestine is critical for maintaining an effective barrier to penetration of antigens $(16,17)$, neither the effect of epithelial cells on reorganizing the extracellular matrix nor the role of intestinal epithelial cells in the repair of surface damage has been directly examined or quantified. Various epithelial cell types, during organization on and within collagen gels, have been reported to deform and partially contract the collagen gels (18-24), and keratinocytes (25), which contract collagen gels in vitro, have been implicated in epithelial wound repair in vivo (26). Intestinal epithelial cells deform and contract collagen gels during organization $(23,24)$, and confluent intestinal epithelial cells grown on a reconstituted basement membrane contract the basement membrane gel surface, reducing its surface area by $90 \%$ (personal observation). These obser- 
vations suggest a role for the intestinal epithelial cells in repair of the mucosal lining and led us to develop a model system to quantify and compare the tractional forces generated by intestinal epithelial cells during their association into a continuous sheet to those generated by fibroblasts. The use of gel contraction to quantify the tractional forces exerted by intestinal epithelial cells has allowed us to examine, for the first time, serum, matrix and cytoskeletal factors involved in gel contraction by intestinal epithelial cells and to compare the tractional forces generated by intestinal epithelial cells to those generated by fibroblasts.

Intestinal epithelial cells contract collagen gels, and the extent of gel contraction was directly related to the number of cells added and inversely related to the collagen concentration of the gel. Actin microfilament function was required for gel contraction, but microtubular function was not. Fetal bovine serum (FBS) was required for maximal gel contraction.

\section{MATERIALS AND METHODS}

Vitrogen, a preparation of predominantly type I collagen, was obtained from Collagen Corp., Palo Alto, California. Cytochalasin B, cytochalasin D, colcemid, vinblastine, cycloheximide, and agarose were obtained from Sigma, St. Louis, Missouri.

Cell Culture. IEC-6 cells, a diploid rat intestinal crypt cell line, and 3T3 fibroblasts were obtained from the American Type Culture Collection, Rockville, Maryland. Human fetal lung fibroblasts (HFL), were obtained from Robert Bienkowski (LIJMC, New Hyde Park, New York). Cells were grown at $37^{\circ} \mathrm{C}$, on tissue culture plastic in Dulbecco's modified Eagle's minimal essential medium (DMEM) with 4.5 g glucose/liter (GIBCO, Grand Island, New York) with $10 \%$ fetal bovine serum (FBS) and antibiotics (penicillin, streptomycin) in an atmosphere of 5\% $\mathrm{CO}_{2}$ and $95 \%$ air. Cells were passaged at $80-90 \%$ confluence. During some experiments, cycloheximide $(25 \mu \mathrm{g} /$ $\mathrm{ml}$ ) was added to the cells $10 \mathrm{~min}$ prior to gel formation. Cycloheximide at $25 \mu \mathrm{g} / \mathrm{ml}$ inhibited protein synthesis by greater than $90 \%$ (data not shown).

Cells during gel contraction had a normal cellular architecture and appeared viable. After gel contraction, cells released from the collagen by collagenase and dispensed with trypsin will attach and replicate on tissue culture plastic at rates similar to preassay rates.

Preparation of Gels. Collagen gels were prepared as previously described by Steinberg et al. (27). Briefly DMEM and collagen (Vitrogen), neutralized to $\mathrm{pH}$ of 7.4 with $\mathrm{NaOH}$, were mixed with a known number of cells. Specifically, $0.4 \mathrm{ml}$ of cells in DMEM with $10 \%$ FBS, 0.26 $\mathrm{ml}$ of $2 \times$ concentrated DMEM with $20 \%$ serum, $0.09 \mathrm{ml}$ of $0.1 \mathrm{NaOH}$, and $0.3 \mathrm{ml}$ of a $500 \mu \mathrm{g} / \mathrm{ml}$ Vitrogen solution (diluted from the stock solution with distilled water) were combined in a tube, mixed, and $0.5 \mathrm{ml}$ of this solution containing the suspended cells was immediately added to 16-mm-diameter culture wells (Lynbro Scientific, Hamden, Connecticut). Each well had been precoated with a film of $0.66 \%$ agarose to prevent cell attachment to the plastic. After plating, the cell suspension in collagen was incubated at $37^{\circ} \mathrm{C}$ in a $95 \%$ air, $5 \% \mathrm{CO}_{2}$ atmosphere, conditions in which collagen fibrils began to form within $10 \mathrm{~min}$.

Measurement of Gel Size. After either 12 or $24 \mathrm{hr}$ in culture as noted in each experiment, three separate diameter measurements differing in orientation by approximately $120^{\circ}$ from one another were made and the average diameter was determined. The area of each gel was calculated from the diameter. The final gel was subtracted from the area originally occupied by the gel, and the percent decrease in gel area during contraction was calculated.

Staining of Collagen Gels. Collagen gels were washed exhaustively with phosphate-buffered saline (PBS), fixed with alcohol-formalin-acetic acid for $2 \mathrm{hr}$, then washed and stored in $70 \%$ ethanol. The gels were washed with PBS and then stained with polychromed methylene blue for $10 \mathrm{~min}$ and destained with $70 \%$ ethanol. The gels were then transferred to slides, mounted in glycerol, examined, and photographed.

Measurement of Thymidine Incorporation. IEC-6 cells $\left(10^{5} /\right.$ well) were attached to a 24 -well tissue culture plate (2 $\mathrm{cm}^{2} /$ well) for $24 \mathrm{hr}$ in DMEM with $10 \%$ FBS. After attachment, cells were preincubated in DMEM with $10 \%$ FBS with and without $5 \mu \mathrm{g}$ of cycloheximide for $1 \mathrm{hr}$. $\left[{ }^{3} \mathrm{H}\right]$ Thymidine $2 \mu \mathrm{g} / \mathrm{ml}$ was then added to the wells, and the cells incubated at $37^{\circ} \mathrm{C}$ for $4 \mathrm{hr}$. The cells were washed, scraped, precipitated with TCA, and the precipitant transferred to millicell filters and washed with $5 \%$ TCA $\times 3$, ethanol $\times 1$ and dried. The $\left[{ }^{3} \mathrm{H}\right]$ thymidine retained on the filter was solubolized with Safety-solve (Research Products International, Mount Prospect, Illinois) solution and counted in a liquid scintillation counter.

Partial Depletion of Fibronectin from FBS. Fetal bovine serum was passed over a gelatin affinity column to remove fibronectin. Passage removed over $90 \%$ of fibronectin from the serum (data not shown).

\section{RESULTS}

Formation of Collagen Gels. Collagen gels measured immediately after formation had an initial diameter of $16 \mathrm{~mm}$ and a surface area of $2 \mathrm{~cm}^{2}$, corresponding to the size and shape of the culture well. The gels contracted progressively over the next $24 \mathrm{hr}$ to an extent determined by the number of cells added and the collagen concentration. IEC- 6 cells, during the gelling process, were distributed primarily on the upper surface of the gel $(80 \%)$, with the remainder of cells (20\%) distributed throughout the gel (results not shown). After $1 \mathrm{hr}$ in culture (Figure 1A), IEC-6 cells were present as individual cells and as small cell aggregates. After $4 \mathrm{hr}$ in 

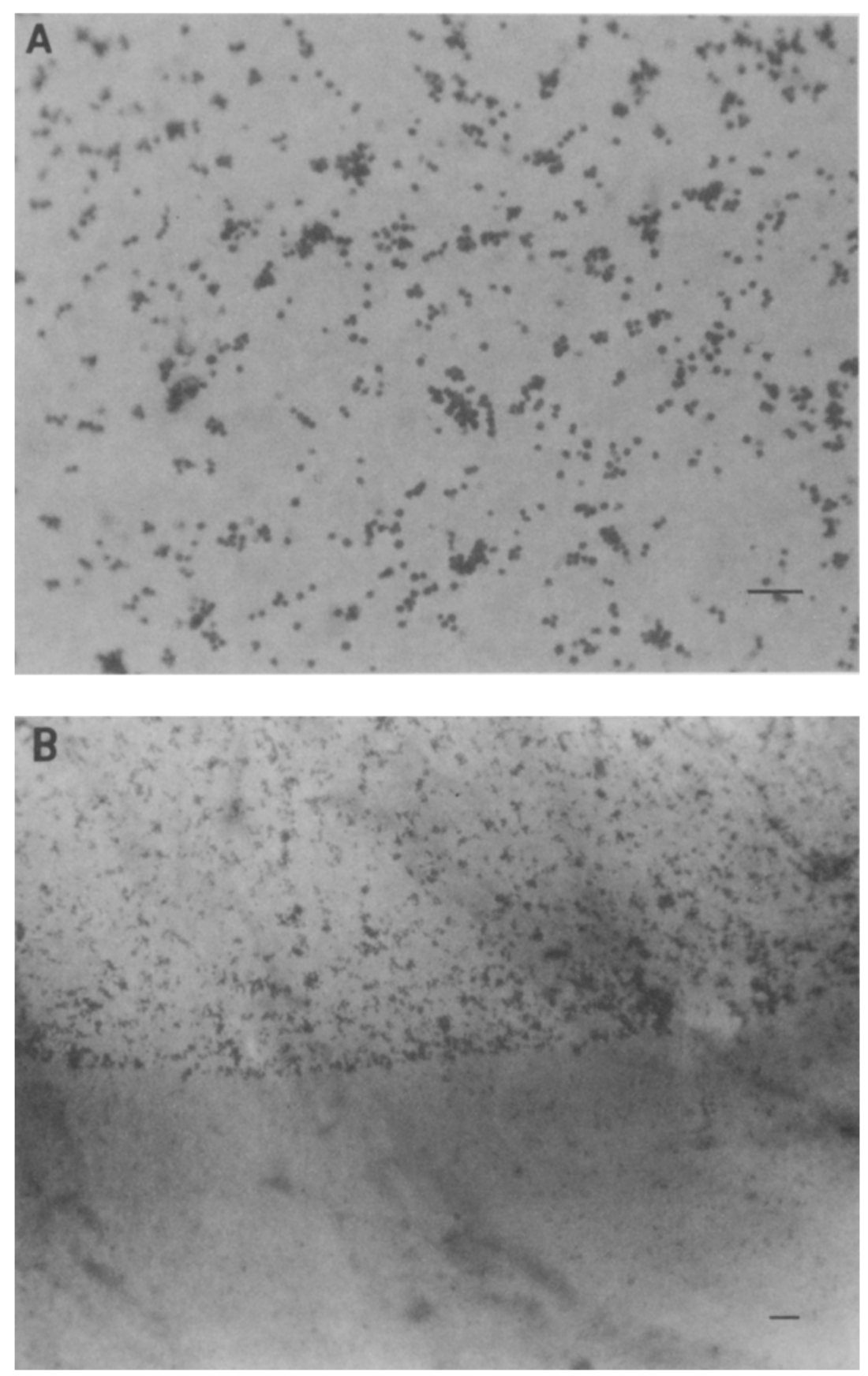

Fig 1. Morphology of IEC-6 cells within collagen gels $(150 \mu \mathrm{g} / \mathrm{ml})$. The IEC-6 cells, after $1 \mathrm{hr}$ in culture, could be seen both as solitary cells and as cell aggregates (A). IEC-6 cells were predominantly located on the upper surface of the collagen gel $(80 \%)$ with the remainder of cells $(20 \%)$ distributed throughout the gel. (The cells within the gel are out of focus) After $4 \mathrm{hr}$ in culture, the gel surface contracted to $60 \%$ of its original area. A marked increase in the number and size of cell aggregates was evident, and a clearly delineated cell-rich central region had developed (B). After $24 \mathrm{hr}$ in culture with a $95 \%$ reduction in surface area, the IEC-6 cells on the upper surface are packed tightly (C,D). $(\mathrm{Bar}=200 \mu \mathrm{m}$.)

culture (Figure 1B), the gel surface had contracted to $60 \%$ of its original area. More multicellular cell aggregates were present, and a continuous confluent ring of cells defined the outer edge of the upper 

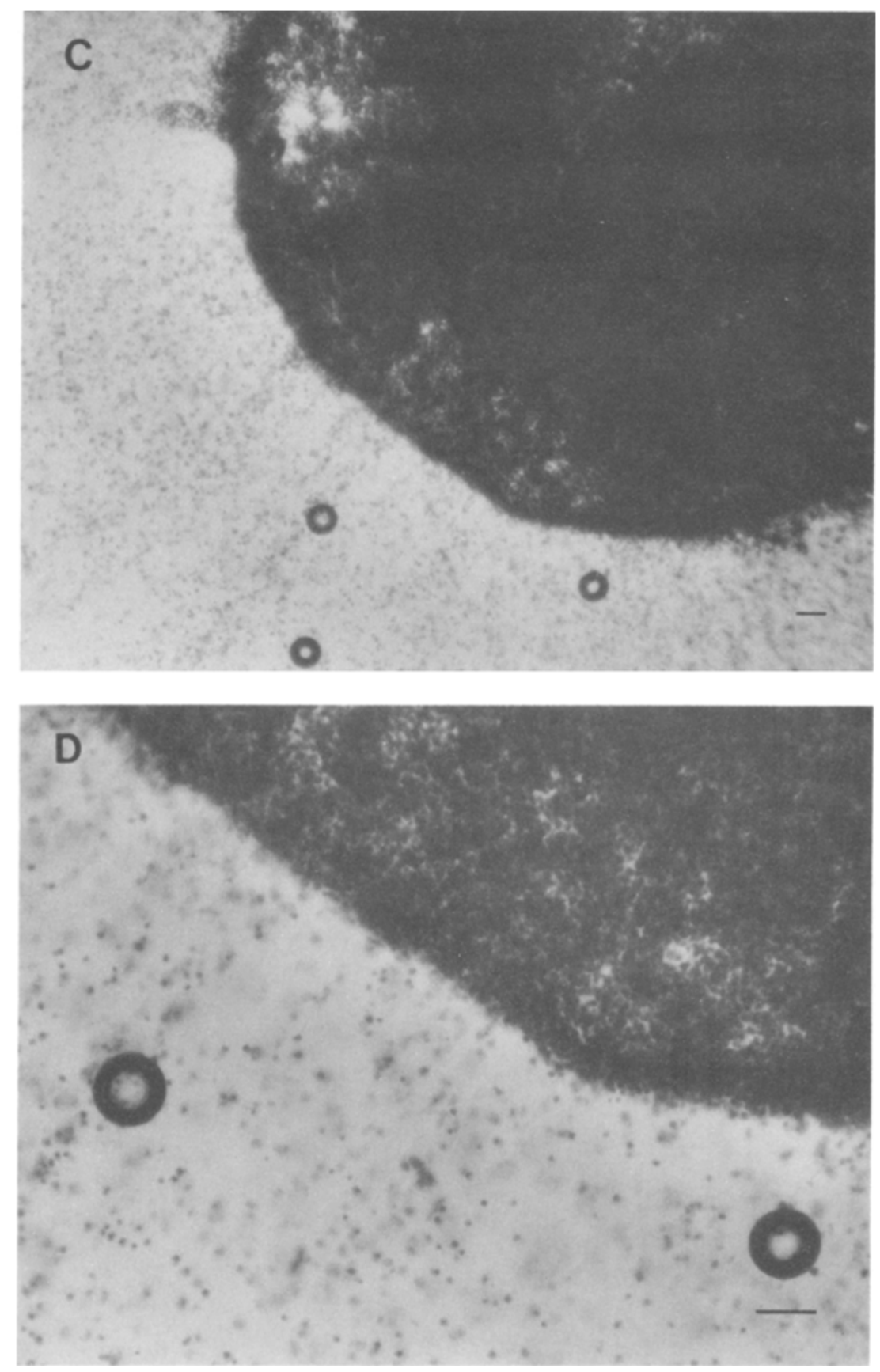

Fig 1. Continued.

gel surface. After $24 \mathrm{hr}$ in culture, the IEC- 6 cells on the surface of the gel were confluent and tightly packed, and the gel surface area had decreased by 95\%. A series of sequential photomicrographs at different focal planes demonstrated the confluent cell sheet was on the gel's upper surface. Only occasional cells were seen throughout the depth of the gel (results not shown). Significant cell replication did not occur in our system during the $24 \mathrm{hr}$ of assay, since the total number of cells released from collagen at $24 \mathrm{hr}\left(9 \times 10^{5}\right)$ was not significantly changed from the preassay number $\left(10^{6}\right)$ and there were no mitotic figures noted on histology.

The degree of gel contraction at $24 \mathrm{hr}$ increased 
as the collagen concentration of the gel was reduced below $870 \mu \mathrm{g} / \mathrm{ml}$. A collagen concentration of 217 $\mu \mathrm{g} / \mathrm{ml}$ or less resulted in maximal gel contraction by $24 \mathrm{hr}$. All subsequent gel contraction experiments were carried out at a concentration of $150 \mu \mathrm{g} / \mathrm{ml}$ of collagen per gel, a convenient concentration that yielded a gel strong enough to handle while giving maximal contraction at $24 \mathrm{hr}$.

Fibronectin Is Required for Maximal Contraction. To examine the role of fibronectin in gel contraction by IEC- 6 cells, we used FBS that was partially depleted of fibronectin by passage of FBS over a gelatin affinity column. To enhance the sensitivity of the gel contraction assay, the extent of gel contraction was examined after $12 \mathrm{hr}$ in culture. To inhibit synthesis of fibronectin by the IEC- 6 cells, cycloheximide $(25 \mu \mathrm{g} / \mathrm{ml})$ was added to the media. Gel contraction was significantly less when serum partially depleted of fibronectin was added (50\% \pm 2.3 decrease in gel surface area) than when untreated FBS was added to the culture medium $(65 \%$ \pm 3.1 decrease in gel surface area) $(P<0.01)$. Addition of fibronectin $200 \mu \mathrm{g} / \mathrm{ml}$ to the serum depleted of fibronectin significantly restored gel contraction $(62 \% \pm 2.8)$ to levels not significantly different from gels formed with 10\% FBS. Gel contraction without serum added was significantly less $(15 \%$ decrease in gel surface area) then gel contraction when serum partially depleted of fibronectin was added $(P<0.01)$.

Comparison of Gel Contraction Efficiency. IEC- 6 cells contracted gels composed of reconstituted, native collagen fibrils with a maximum reduction in gel area of $97 \%$ (Figure 2). The extent of gel contraction was dependent upon the number of cells added. When $10^{4}$ cells or less were added to the gel, no contraction occurred during the 24-hr experimental period. As the number of cells added to the gel increased, the extent of gel contraction increased. When $8 \times 10^{6}$ cells or greater were added per well, maximal gel contraction occurred by 24 hr. 3T3 and human fetal lung (HFL) fibroblasts showed a similar relationship between the number of cells added per well and the extent of gel contraction, but fewer fibroblasts than epithelial cells were required for the same degree of gel contraction. $3 \mathrm{~T} 3$ and HFL fibroblasts produced $50 \%$ gel contraction with only $5 \times 10^{4}$ cells, while IEC- 6 cells at passage 16 required $5 \times 10^{5}$ cells and IEC- 6 cells at passage 26 required $8 \times 10^{5}$ cells for $50 \%$ gel contraction (Figure 3). All subsequent experiments with IEC-6 cells used $10^{6}$ cells/gel at passage 16 .

\section{GEL CONTRACTION BY IEC-6 CELLS}

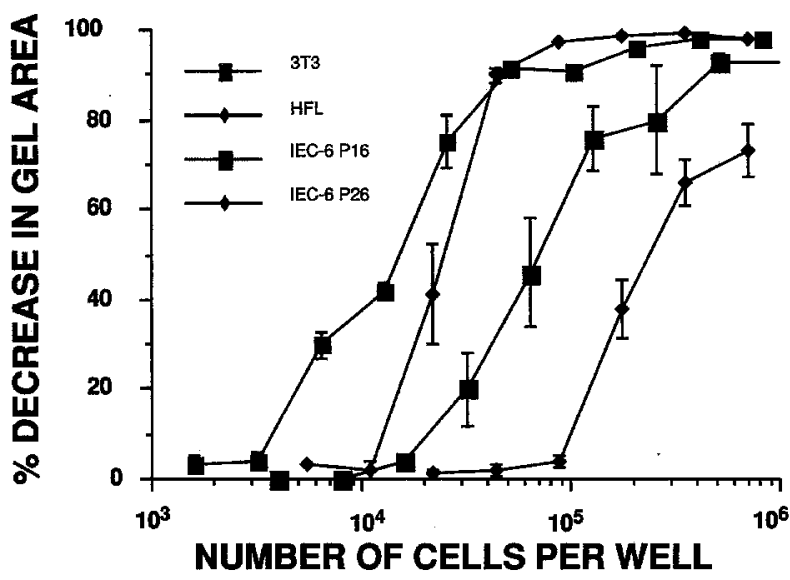

Fig 2. Comparison of gel contraction by epithelial cells and fibroblasts. The percent decrease in gel area is indicated on the $y$ axis. The number of cells added to each well is indicated by a logarithmic scale on the $x$ axis. (IE-4 indicates $1 \times 10^{4}$ cells.) The number of cells added to each well was varied from one thousand to two million cells. Four cell populations were used, 3T3 fibroblasts, human fetal lung (HFL) fibroblasts, IEC-6 cells at passage 18 , and IEC- 6 cells at passage 28 . Collagen gels were prepared as indicated in Materials and Methods $(150 \mu \mathrm{g} / \mathrm{ml})$. After allowing the gel to contract for $24 \mathrm{hr}$, the diameter of the gel was determined, the area of the gel calculated, and the percent decrease in surface area determined. Each point represents the average percent decrease in surface area determined from four gels. 3T3 and HFL fibroblasts required $5 \times 10^{4}$ cells for $50 \%$ reduction of the gel surface area, while IEC- 6 cells at low passage required 5 $\times 10^{5}$ cells and at late passage required $8 \times 10^{5}$ for a $50 \%$ reduction of the gel surface area.

Role of Cytoskeletal Structures in Gel Contraction. We examined the effect of inhibitors of cytoskeletal function on gel contraction. Cytochalasin B (5-50 $\mu \mathrm{g} / \mathrm{ml})$ and cytochalasin $D(1-50 \mu \mathrm{g} / \mathrm{ml})$, inhibitors of actin microfilament assembly, inhibited gel contraction in a dose-dependent fashion (Figure 3). Colcemid $(150 \mu \mathrm{g} / \mathrm{ml})$ and vinblastine $(5 \mu \mathrm{g} / \mathrm{ml})$, at dosages reported to inhibit microtubular function, did not affect gel contraction; neither compound altered the degree of gel contraction when compared with matched control cultures.

IEC-6 Cells Contract Collagen Gel in Absence of Fetal Bovine Serum. We examined the effect of FBS on gel contraction. Without FBS, gel contraction at $24 \mathrm{hr}$ resulted in only a $70 \% \pm 1.2$ reduction in surface area in contrast to the $97 \% \pm 0.8$ reduction in surface area when $10 \%$ FBS was added $(P<$ 0.01 ) (Figure 4). Addition of $1 \%$ fetal bovine serum increased gel contraction to a $95 \% \pm 2.1$ reduction of surface area, significantly greater than the $70.1 \%$ \pm 1.2 with no FBS added $(P<0.01)$. These results suggested that gel contraction could be sustained in 
ROLE OF CYTOSKELELTAL STRUCTURES IN GEL CONTRACTION

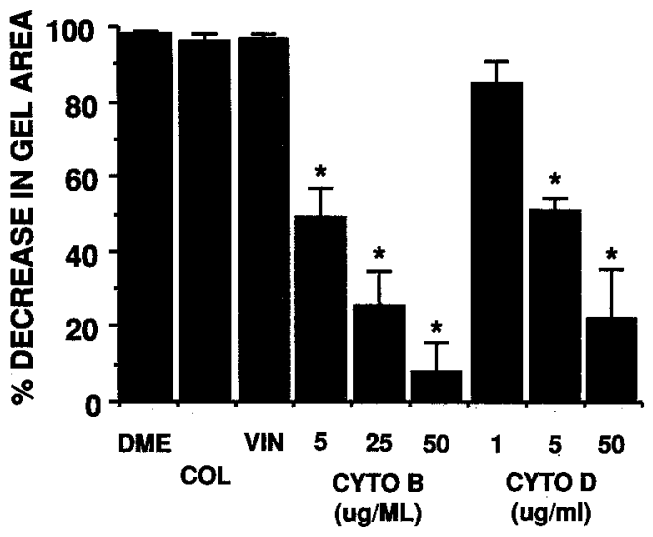

Fig 3. Gel contraction was measured using collagen gels formed with $150 \mu \mathrm{g} / \mathrm{ml}$ of collagen with $1 \times 10^{6}$ cells added prior to gelation. Cells were exposed to colcemid $(150 \mu \mathrm{g} / \mathrm{ml})$, vinblastine $(5 \mu \mathrm{g} / \mathrm{ml})$, cytochalasin B $(5-50 \mu \mathrm{g} / \mathrm{ml})$, and cytochalasin D (1-50 $\mu \mathrm{g} / \mathrm{ml}) 10 \mathrm{~min}$, prior to gel formation. Gel diameters were measured at $24 \mathrm{hr}$, the gel area calculated, and the percent decrease in gel area determined. The extent of gel contraction was measured as the percent decrease in the surface area of the gel as indicated on the $y$ axis. The additives are indicated on the $x$ axis (colcemid, vinblastine, cytochalasin $\mathrm{B}$, and cytochalasin $\mathrm{D}$ ). Cytochalasin B and cytochalasin D, inhibitors of actin microfilaments, inhibited gel contraction $(P<0,001)$ while colcemid and vinblastine, inhibitors of microtubules, did not.

\section{EFFECTS OF CYCLOHEXAMIDE ON GEL CONTRACTION}

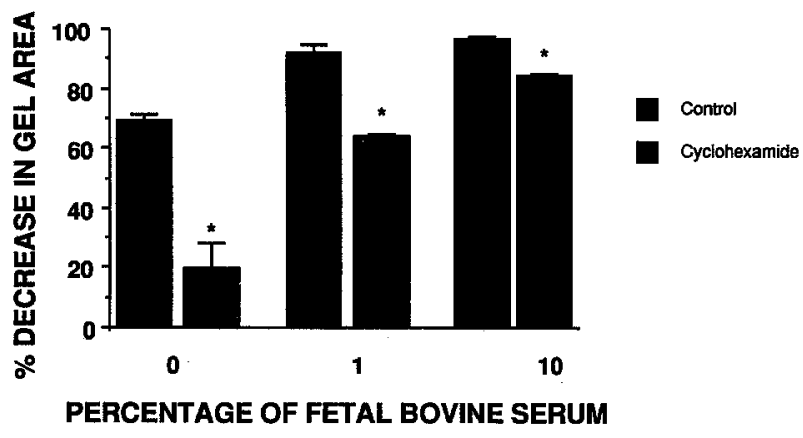

Fig 4. IEC-6 cells, $1 \times 10^{6}$ per well, were incorporated into collagen gels, $150 \mu \mathrm{g} / \mathrm{ml}$, as noted above. Cyclohexamide, 25 $\mu \mathrm{g} / \mathrm{ml}$, was added $10 \mathrm{~min}$ prior to gel formation where indicated, with the concentration of FBS varying from 0 to $10 \%$, as indicated. Gels were allowed to contract for $24 \mathrm{hr}$, at which time the gel diameter was measured, the area calculated, and the percent decrease in gel area determined. Gel contraction was significantly decreased when protein synthesis was inhibited by cycloheximide $(25 \mu \mathrm{g} / \mathrm{ml})$ at all FBS concentrations $(P<0.01)$. Maximum gel contraction, however, occurred in the presence of $10 \%$ FBS. The greatest decrease in gel contraction in response to addition of cycloheximide occurred in the absence of FBS $(P<$ 0.001 ). the absence of FBS, but that its elimination decreased significantly the extent of gel contraction.

Inhibition of Protein Synthesis Increases FBS Requirements for Maximal Gel Contraction. To investigate the role of protein synthesis in gel contraction, we examined the effect of cycloheximide on gel contraction. Addition of cycloheximide at a dose of $25 \mu \mathrm{g} / \mathrm{ml}$, a dose that inhibited protein synthesis by IEC- 6 cells by $95 \pm 3 \%(N=4)$, significantly decreased gel contraction at all FBS concentrations examined (Figure 4). In the absence of fetal calf serum, cycloheximide inhibited gel contraction to the greatest extent, with a decrease in the extent of gel contraction from a $70 \% \pm 2.5$ decrease in surface area without cycloheximide to a $20.1 \% \pm 9.8$ decrease in gel surface area with cycloheximide $(P<0.001)$ (Figure 4$)$. The gel surface area had decreased by only $20.1 \% \pm 9.2$ at $24 \mathrm{hr}$ (Figure 4). Addition of 1\% FBS to the culture medium resulted in a significant recovery of gel contraction in the presence of cycloheximide. When a $1 \%$ or $10 \%$ FBS concentration was used, there was a $68 \% \pm 0.8$ and $87 \% \pm 0.5$ reduction in surface area $(P<0.01)$. These results were repeated in three separate experiments. This suggests that either the effect of inhibition of protein synthesis could be reversed by serum factors or serum prevented cell toxicity due to cycloheximide.

\section{DISCUSSION}

In this study, we present a model to examine and quantify the interaction of epithelial cells and the extracellular matrix. We have compared the tractional forces generated by epithelial cells with those generated by fibroblasts during contraction of gels composed of reconstituted native collagen fibrils. IEC- 6 cells reduced the collagen gel surface area by greater than $95 \%$. Although fibroblasts and epithelial cells both increased the extent of gel contraction as the number of cells added to the gel increased, comparison of the number of cells required for $50 \%$ contraction of collagen gels $\left(1\right.$ and $0.9 \times 10^{5}$ cells for the HFL and 3T3 fibroblasts versus $5 \times 10^{5}$ for the IEC- 6 cells at passage 16) indicates that IEC-6 cells are less efficient than fibroblasts in contracting a collagen gel. This observed difference in contraction efficiency between IEC-6 cells and fibroblasts may be related to either an intrinsic difference in cell function or to the differing distribution of the two cell types during formation of the collagen gels.

Our findings with intestinal epithelial cells are 
EFFECT OF PARTIAL DEPLETION OF FIBRONECTIN FROM FETAL BOVINE SERUM ON GEL CONTRACTION

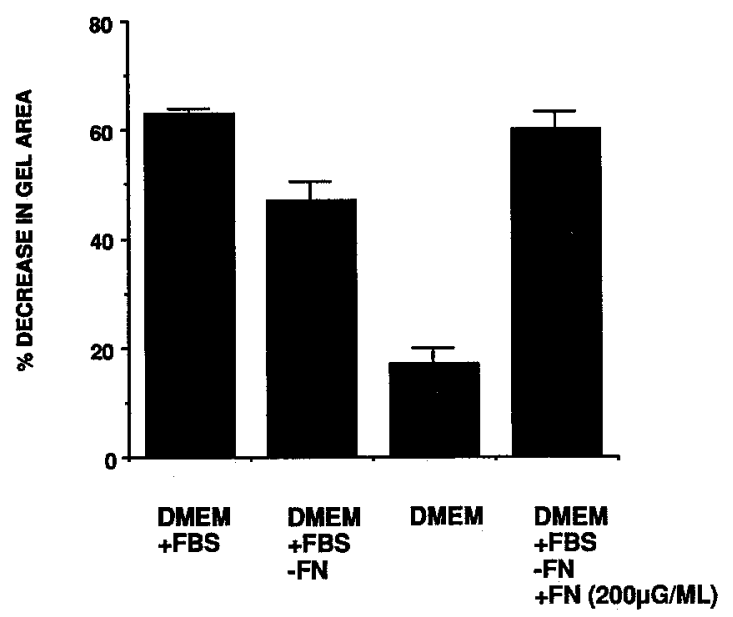

Fig 5.

similar to the contraction of collagen gels by kerotinocytes (25) and extend and quantitate the observed deformation of collagen gels by mammary epithelial cells and IEC of Hall et al (20) and Montgomery (22) respectively.

IEC-6 cells at high passage have a lower efficiency of contraction than low passage cells. This finding may relate to the reported loss in contractile efficiency of fibroblasts after malignant transformation (27). Both progressive aging and malignant transformations may affect efficiency of contractile elements. Thus, the passage number of epithelial cells, like that of fibroblasts, should be kept in mind when measuring tractional forces generated by either cell type.

The observations that the actin microfilament network is a critical element required for matrix reorganization is similar to what is reported in fibroblasts (15), where cytochalasin has also been shown to inhibit gel contraction.

Decreasing the amount of fibronectin by column extraction in the extracellular environment reduces the degree to which IEC-6 cells can contract a collagen gel under standard experimental conditions. However, other factors than fibronectin may be removed by the column extraction. Reversal of this inhibition by addition of fibronectin to fibronectin-depleted serum confirms that fibronectin is required for optimum gel contraction. This requirement is similar to the requirement for fibronectin reported for fibroblasts (10). Inhibition of protein synthesis, including fibronectin synthesized by IEC-6 cells (28), also decreased the degree of gel contraction. However, the degree of gel contraction observed with FBS partially depleted of fibronectin suggests that serum factors other than fibronectin are also necessary to achieve maximal gel contraction.

This model system permits quantification of the tractional forces generated by epithelial cells. This system can be useful in determining the role that various elements (eg, extracellular matrix molecules, extracellular matrix cell surface receptors, cytoskeletal elements) play in the organization of extracellular matrix by epithelial cells. The experimental system that we developed has several advantages, including the availability of a commercially prepared collagen; the rapid, reproducible extent of contraction; the well-defined gel composition; and the easily measured and reproducible end point. The collagen concentration used in this model, which is lower, and the cell number, which is higher, than those previously reported using fibroblasts $(8,27)$, permit the determination of gel contraction within $24 \mathrm{hr}$.

The importance of contraction of the intestinal villus following damage to the intestinal surface has been illustrated (29), suggesting an important role for the myofibroblast in contraction of the intestinal villus. A potential role of the intestinal epithelial cell sheet covering the villus surface in this repair process, although not directly examined in these studies, is suggested by the tension documented in our system in vitro. The relative roles of the myofibroblast and the potential force generated by intestinal epithelial cells on the surrounding matrix should both be considered in future models of intestinal development and repair.

\section{APPENDIX: REDUCTION OF FIBRONECTIN CONTENT OF FETAL BOVINE SERUM INHIBITS GEL CONTRACTION}

To examine the role of fibronectin in gel contraction by IEC- 6 cells, we used FBS that was partially depleted of fibronectin by passage of FBS over a gelatin affinity column. Gel contraction was examined after $12 \mathrm{hr}$ in culture with cycloheximide ( 25 $\mu \mathrm{g} / \mathrm{ml}$ ) added to the media. Gel contraction was significantly less when serum partially depleted of fibronectin was added (DMEM + FBS - FN) $(50 \%$ \pm 2.3 decrease in gel surface area) (Figure 5) than 
when FBS was added to the culture medium $(\mathrm{DMEM}+\mathrm{FBS})(65 \% \pm 3.1$ decrease in gel surface area) (Figure 5) $(P<0.01)$. Addition of fibronectin $200 \mu \mathrm{g} / \mathrm{ml}$ to the serum partially depleted of fibronectin (DMEM + FBS - FN + FN, $200 \mu \mathrm{g} / \mathrm{ml}$ ) increased the extent of gel contraction $(62 \% \pm 2.8)$ (Figure 5) (NS compared to FBS). Gel contraction without serum added (DMEM) (15\% reduction in gel surface area) (Figure 5) was significantly less than the extent of gel contraction when serum partially depleted of fibronectin was added $(P<0.01)$.

\section{ACKNOWLEDGMENTS}

The author wishes to thank Colleen Croxall for her help in preparing this manuscript.

\section{REFERENCES}

1. Kleinman HK, McGarvey ML, Hassell JR, Star VL, Cannon FB, Laurie GW, Martin GR: Basement membrane complexes with biological activity. Biochemistry 25:312-318, 1986

2. Klienman HK, McGarvey ML, Hassell JR, Martin GR, Baron von Evercooren A, Dubois-Dalccq M: The role of laminin in basement membranes and in the growth, adhesion, and differentiation of cells. The role of extracellular matrix in development. 123-143, 1984

3. Quaroni A: Development of fetal rat intestine in organ and monolayer culture. J Cell Biol 100:1611-1622, 1985

4. Olson AD, Pysher T, Bienkowski RS: Organization of intestinal epithelial cells into multicellular structures requires laminin and functional actin microfilaments. Exp Cell Res 192:in press, 1991

5. Dunn G, Heath J: A new hypothesis of contact guidance in tissue cells. Exp Cell Res 101:1-14, 1976

6. Dunn G, Ebendal T: Contact guidance on oriented collagen gels. Exp Cell Res 111:475-479, 1978

7. Elsdale T, Bard J: Collagen substrata for studies on cell behavior. J Cell Biol 54:626-637, 1972

8. Farsi JMA, Aubin JE: Microfilament rearrangements during fibroblast-induced contraction of three-dimensional hydrated collagen gels. Cell Motil 4:29-40, 1984

9. Guidry C, Grinnell F: Contraction of hydrated collagen gels by fibroblasts: Evidence for two mechanisms by which collagen fibrils are stabilized. Collagen Relat Res 6:515-529, 1987

10. Fukamizu H, Grinnell F: Spatial organization of extracellular matrix and fibroblast activity: Effects of serum, transforming growth factor beta, and fibronectin. Exp Cell Res 190:276-282, 1990

11. Grinnell F, Fukamizu H, Pawelek P, Nakagawa S: Collagen processing, crosslinking, and fibril bundle assembly in matrix produced by fibroblasts in long-term cultures supplemented with ascorbic acid. Exp Cell Res 181:483-491, 1989

12. Schor S, Schor A: Foetal-to-adult transitions in fibroblast phenotype: Their possible relevance to the pathogenesis of cancer. J Cell Sci Suppl 8:165-180, 1987
13. Allan T, Schor S: The contraction of collagen matrices by dermal fibroblasts. J Ultrastruct Res 83:205-219, 1983

14. Bell E, Ivarsson B, Merrill C: Production of a tissue-like structure by contraction of collagen lattices by human fibroblasts of different proliferative potential in vitro. Proc Natl Acad Sci USA 76(3):1274-1278, 1979

15. Guidry C, Grinnell F: Studies on the mechanism of hydrated collagen gel reorganization by human skin fibroblasts. J Cell Sci 79:67-81, 1985

16. Harmatz P, Bloch K, Brown M, Walker W, Kleinman R: Intestinal adaptation during lactation in the mouse. I. Enhanced intestinal uptake of dietary protein antigen. Immunology 67:92-95, 1989

17. Istael E, Walker W: Host defense development in gut and related disorders. Pediatr Clin North Am 35:1-15, 1988

18. Barcellow-Hoff M, Aggeler H, Ram T, Bissell M: Functional differentiation and alveolar morphogenesis of primary mammary cultures on reconstituted basement membrane. Development 105:223-235, 1989

19. Schor A, Schor S, Allen T: Effects of culture conditions on the proliferation, morphology and migration of bovine aortic endothelial cells. J Cell Sci 62:267-285, 1983

20. Hall $\mathrm{H}$, Farson D, Bissell M: Lumen formation by epithelial cell lines in response to collagen overlay: A morphogenetic model in culture. Proc Natl Acad Sci USA 79:4672-4676, 1982

21. Bissell DM, Arenson DM, Maher JJ, Roll FJ: Support of cultured hepatocytes by a laminin-rich gel. Evidence for a functionally significant subendothelial matrix in normal rat liver. J Clin Invest 79:801-812, 1987

22. Montgomery RK: Morphogenesis in vitro of dissociated fetal rat small intestinal cells upon an open surface and subsequent to collagen gel overlay. Dev Biol 117:64-70, 1986

23. Montgomery RK, Zinman HM, Smith BT: Organotypic differentiation of trypsin-dissociated fetal rat intestine. Dev Biol 100:181-189, 1983

24. Li ML, Aggeler J, Farson DA, Hatier C, Hassell J, Bissell MJ: Influence of a reconstituted basement membrane and its components on casein gene expression and secretion in mouse mammary epithelial cells. Proc Natl Acad Sci USA $84: 136-140,1987$

25. Schafer I, Shapiro A, Kovach M, Lang C, Fratianne R: The interaction of human papillary and reticular fibroblasts and human keratinocytes in the contraction of three-dimensional floating collagen lattices. Exp Cell Res 183:112-125, 1989

26. Grinnell $F$ : The activated keratinocyte: $U p$ regulation of cell adhesion and migration during wound healing. J Trauma 30:S144-S149, 1990

27. Steinberg BM, Smith K, Colozzo M, Pollack R: Establishment and transformation diminish the ability of fibroblasts to contract a native collagen gel. J Cell Biol 87:304-308, 1980

28. Quaroni A, Isselbacher KJ, Ruoslahti E: Fibronectin synthesis by epithelial crypt cells of rat small intestine. Proc Natl Acad Sci USA 75(11):5548-5552, 1978

29. Nusrat A, Madara J: Characterization of intestinal epithelial cell motility in a model of restitution. Gastroenterology 100:A699, 1991 